\title{
The Role of Personal Values in Social Entrepreneurship
}

\author{
Hüseyin Akar*, Yıldız Burcu Doğan \\ Department of Educational Sciences, Kilis 7 Aralık University, Turkey
}

Copyright $\mathrm{C} 2018$ by authors, all rights reserved. Authors agree that this article remains permanently open access under the terms of the Creative Commons Attribution License 4.0 International License

\begin{abstract}
The purpose of this research is to examine to what extent pre-service teachers' personal values predict their social entrepreneurship characteristics. In this context, statistical analysis was conducted on the data obtained from 393 pre-service teachers studying at the Faculty of Muallim Rifat Education at Kilis 7 Aralık University in 2016-2017 academic semester. The data was collected through social entrepreneurship and personal value scales. The results of the data analysis indicated the mean scores for pre-service teachers' perceptions for social entrepreneurship at mostly level, for self-control and intellectualism values at agreement level and religiousness, social skills and honesty values at moderate agreement level. It was found out that there is a moderate positive relationship between pre-service teachers' religiousness, social skill, honesty and self-control values and their social entrepreneurship, while there is a low positive relationship between intellectualism and their social entrepreneurship. Besides, religiousness, social skill, honesty, self-control and intellectualism values significantly predicted pre-service teachers' social entrepreneurships and accounted for $40 \%$ of the total variance. In this regard, it can be stated that personal values have a decisive role on social entrepreneurship activities.
\end{abstract}

Keywords Personal Values, Social Entrepreneurship, Pre-service Teacher

\section{Introduction}

Nowadays in the world, one in nine people lives in hunger and one in three people is undernourished. About 15 million girls marry before the age of 18 each year. 18 million people die due to air pollution all around the world every day. Women are exposed to discrimination in possession and in many other fields in a number of societies. It is estimated that more than one million people sustain their lives in physically or mentally disabled ways, are tagged in society and exposed to discrimination. Millions of people are exposed to natural disasters and droughts with regard to climate in degenerated and eroded soil. 3.3 million hectares of forestland have been destroyed all over the world. According to the official unemployment statistics, 204 million people, of whom 74 million are young, are unemployed. There are 100 million boys and 68 million girls in child labor all over the world. 780 million adults and 103 million youths are illiterate. 160 million people are not functionally literate in the developed countries. In a global scale, 250 million children are not learning basic skills though 130 million children of them study at schools for at least four years [1]. Based on the human development report, there are a numbers of matters to be overcome in the world and in Turkey. These matters are increasing by varying day by day and are threatening human life. In this respect, social entrepreneurship and social entrepreneurs are needed more than ever.

Social entrepreneurship is a sort of entrepreneurship and diverges from traditional one with regard to several aspects [2]. It essentially contains social and entrepreneurship features and in the simplest form, it involves dealing with social matters through entrepreneurship point of view [3]. Although the social entrepreneurship concept has appeared as a recent concept, people and organizations have always been involved in social entrepreneurship activities throughout history. When it is examined in conceptual respect, it is known that it was, for the first time, used in the research conducted in the social change field in 1972. However, it was commonly used in the 1990s. Ashoka organization founded in 1981 to promote social entrepreneurship and Schwab Foundation founded in 1998 have contributed to becoming the concept widespread. Besides, the fact that the Nobel Peace Prize was awarded to Muhammad Yunus in 2006 due to the contributions for the Grameen Bank which was founded under his leadership to provide people with microcredit to encourage social entrepreneurship has played a significant role in developing the concept [4]. Nowadays it is seen that the concept attracts intensive attention in academia. Nevertheless, it is understood that there is not a common consensus on the definition of the concept despite the increased interest in social entrepreneurship issue. When the literature is examined, several definitions are encountered in individual, organizational and social levels [5]. The majority of the studies dealing with social 
entrepreneurship are concerned with the explanation and definition of the concept. In general sense, social purposes and entrepreneurship activities variables come into prominence [6]. In this regard, social entrepreneurship is defined as social purposeful entrepreneurship activities. There has to be a social purpose in every social entrepreneurship activities since it essentially aims to create a social value. When the social entrepreneurship definitions at individual levels are examined, it is seen that social entrepreneurs are defined as change agents who have social purposes, act to ensure social justice, mobilize ideas, skills, resources and regulations which are necessary for social transformation and create innovative solutions for social problems $[2,7,8]$. According to Reis [2], social entrepreneurs create social value to enable the developments in social and economic domains by utilizing economic resources through an innovative understanding. According to Nicholls [10], as social entrepreneurs deal with the social problems with respect to an innovative understanding, they act as a driving power in social and economic development.

Social entrepreneurs focus on innovative and enterprising approaches to determine social problems and provide solutions for problems in short and long term [11], present business models to solve problems and meet complicated social needs [12]. In this regard, they have a significant role in coming up with creative solutions for complicated and ongoing social matters which do not attract the attention of the commercial, public and non-governmental organizations [13]. They are inclined to go into action when they see a problem in the environment and society where they live. Their primary purpose is not to make money or profit. On the contrary, their purpose is to solve the society's problems, meet its needs and interests $[14,2,15]$. So, social entrepreneurship processes are similar to traditional or commercial entrepreneurships though they differentiate from the other entrepreneurships with regard to purpose and motivation. Interest for social incentives in all social entrepreneurship studies has become a central pre-requisite issue. Furthermore, this issue is accepted as a distinctive characteristic for social entrepreneurship. Entrepreneurs and social entrepreneurs are distinguished with each other with regard to profit motivation [16]. There is a consensus among researchers that social entrepreneurs are motivated with social purposes to gain favor to society [17]. From this aspect, social entrepreneurs' purposes are not just to produce something new to gain reputation or make economic gains; rather make the world more livable place.

While social entrepreneurs' purposes are to find lost-lasting solutions for social problems and create social values, they also have to make economic profit to sustain their missions. Economic value does not represent an ultimate aim for a social entrepreneur. However, it should be seriously dealt with, for it represents a crucial side effect to sustain innovation, enterprises and economy [18]. Social entrepreneurs are also in a struggle to meet society's unfulfilled needs, prepare and apply their own programs in this respect, produce new services and products [19]. The research in this field indicates that the activities concerned with social entrepreneurship increase economic growth, develop a society's quality of life, decrease poverty and substantially enable social change $[13,19,20]$.

When social entrepreneurs' characteristics are examined, it is seen that they need to have courage, self-confidence, responsibility, determination, resolution, and knowledge in a particular area [21]. According to Knörr, Alvarez and Urbano [22], creativity, risk taking and independence increases the possibility of being entrepreneur. Entrepreneurs are defined by Shaw and Carter [23] that they are motivated, determined, ambitious, charismatic leaders and they can deliver vision, inspire others and utilize resources at optimum level. It is seen in the study by Akar and Üstüner [24] that social entrepreneurs' emotional intelligence and self-efficacy perceptions are high. According to Aydin and Akar [25], social entrepreneurs have extraversion and openness personality traits. A number of factors play a significant role in revealing behaviors concerned with social entrepreneurship. Individuals' personal values, undoubtedly, have a significant impact on social entrepreneurship activities.

Values are accepted as belief systems which come into exist in an individual's early life phase and are shaped through life experiences [26]. Values are principles which lead an individual's choices, evaluations with regard to a variety of people and cases [27]. They are the most important determiners of social attitudes, ideologies and behaviors [28]. They are views which represent beliefs with respect to what is good, desirable and right and are continuous and shared by societies and individuals [29]. In other words, personal values are variables which influence an individual's motivation to think and take action [30] and account for how an individual's conscious thoughts and intentions go into action [31]. An individual's values develop by interacting with other people and living experiences [32]. Personal values can show variations according to circumstances in social construct and living experiences. The reason why the individuals living in the same society and having the same cultural characteristics behave differently can be accounted for the fact that they have different personal values [33]. Values influence individuals' vocational and personal lives, attitudes, relationships, interactions with people and attitudes to life. In this regard, values are the most important determiners for individuals' personal, social and vocational choices [34]. Every individual has a set of values which show variations in importance degree. A particular value can be important for an individual, while that value can be unimportant for another [35]. Knowing other individuals' values can enable an individual to make positive relationships with them and to decrease the conflicts which can take place [36]. Individuals can gain others' confidence behaving 
appropriately according to their values [37]. Values play a significant role in increasing and sustaining self-regulation and self-respect and making decisions. Values should be mobilized to lead behavior. Circumstances play an important role in activating values. To illustrate, security value becomes more obvious when a traffic accident occurs. The research concerning the mobilization of the value indicate when a particular value is mobilized, people exhibit behavior according to that particular value [38] However, giving importance to value also determines its mobilization. In this regard, important values are more likely to be turned into behavior [39]. Schwartz [40] determined 10 different universal values with regard to conceptual framework. They are power, achievement, hedonism, stimulation, self-direction, universalism, benevolence, tradition, conformity and security. Scott [41] tried to measure 12 basic values in his own scale: Intellectualism, kindness, social skills, loyalty, academic achievement, physical development, status, honesty, religiousness, self-control, creativity and independence. In the current research, intellectualism, honesty, self-control, religiousness and social skills values were used. Intellectualism refers to those individuals who have the capacity to understand, think, reason and are interested in international, national and regional issues. Honesty refers to those who are credible and sincere and stress out the truth every time and place. Self-control refers to those who have control over their emotions and behaviors. Religiousness refers to those who believe in divine supernatural powers which control humans' destiny, obey and worship them. Social skill refers to those who can communicate and interact with other people, behave according to communal living $[42,43]$.

Education institutions are social open systems which are affected by changes taking place in social construct and environment and at the same time affect social construct and environment through their services and outcomes. Education systems should be institutions which can create sustainable innovative solutions for the disturbing matters at regional, national and international levels in addition to contributing to new generations' physical, cognitive, social and cultural developments. This can just be possible with the social entrepreneur teachers who are sensitive to the matters which increasingly continue in today's world economic, social and health fields such as wars, natural disasters, poverty, unemployment, hunger, various diseases, human rights and justice, education and sheltering [25] and embrace a social mission to find outstanding solutions to these mattes, and the social entrepreneur individuals who will be raised by these teachers. Teachers undertake significant duties to make the world more livable place. In this regard, it is necessary to identify the influential factors which encourage teachers to social entrepreneurship and reveal the behaviors for social entrepreneurship. In the scope of this research, the effects of the personal values, which have impact on individuals' behaviors [38], on pre-service teachers' social entrepreneurship will be investigated. In this context, answers for the following questions were sought.

- Does self-control value significantly predict pre-service teachers' social entrepreneurship characteristics?

- Does religiousness value significantly predict pre-service teachers' social entrepreneurship characteristics?

- Does intellectualism value significantly predict pre-service teachers' social entrepreneurship characteristics?

- Does social skill value significantly predict pre-service teachers' social entrepreneurship characteristics?

- Does honesty value significantly predict pre-service teachers' social entrepreneurship characteristics?

\section{Materials and Methods}

This is a descriptive and cross-sectional study. Relational screening model was used in this study to examine the relationships between pre-service teachers' personal values and their social entrepreneurship characteristics. The Relational screening model aims to determine entity and/or degree of change among two or more variables [44]. The dependent variable of the study is social entrepreneurship. The independent variables of the study are personal values such as self-control, religiousness, intellectualism, social skill and honesty.

\subsection{Population and Sampling}

The population of the research consists of 1100 pre-service teachers studying at different subject areas and grades at the Faculty of Muallim Rifat Education at Kilis 7 Aralık University. Any sampling method was not chosen to reach all the population. Participation into the research was voluntary. In this regard, 393 pre-service teachers voluntarily participated into the research. Participants were $58.5 \%$ females and $41.5 \%$ males. $23.7 \%, 23.2 \%, 21.2 \%, \quad 14.8 \%$ and $17.1 \%$ of the pre-service teachers study in social sciences, pre-school, primary school, sciences and Turkish teaching training programs, respectively. $30 \%, 28.2 \%, 23.9 \%$ and $17.8 \%$ of them study in the first year, second year, third year and fourth year of the aforementioned programs, respectively.

\subsection{Data Collection Instruments}

Data was collected from the participants through pre-service teachers' social entrepreneurship scale, university students' personal values scale and personal information form. 
Pre-service teachers' social entrepreneurship scale: The 21 itemed scale developed by Konaklı and Göğüş [45] aims to measure pre-service teachers' social entrepreneurship levels. Five-point Likert-point scaling is used in the scale. The fit index values $\left(\chi^{2} / \mathrm{sd}=427.15 / 186\right.$ $=2.29 ; \mathrm{RMSEA}=.06 ; \mathrm{NFI}=.90 ; \mathrm{NNFI}=.95 ; \mathrm{CFI}=.95$; $\mathrm{GFI}=.90 ; \mathrm{AGFI}=.86)$ are seen to be at desired level as a result of the analysis conducted by Konaklı and Göğüș [45]. Cronbach Alpha coefficient for the scale is reported to be .85 . In the context with this research, Cronbach Alpha coefficient for the scale was found as .93.

University students' personal values scale: Scott's Personal Values Scale was firstly adapted by Ültanır (1992) and developed by Gökçe [43]. The scale comprises of 29 items and 5 sub-dimensions. It consists of Self-control, Religiousness, Intellectualism, Social skill and Honesty sub-dimensions. It is a Three-point Likert -point scaling, namely "I disagree, I moderately agree, and I agree". Cronbach Alpha coefficient was calculated for self-control sub-dimension as .75, religiousness sub-dimension as .78, intellectualism sub-dimension as .72 , social skill sub-dimension as .76 and honesty sub-dimension as .70.

\subsection{Data Analysis}

Statistical methods such as arithmetic mean, standard deviation, percentage, frequency and correlation analysis were used to analyze the data. Besides, multiple regression analysis was utilized to investigate to what extent pre-service teachers' personal values predict their social entrepreneurship characteristics. Data was analyzed through SPSS packaged software. Significance level was accepted as .05 .

\section{Findings}

Arithmetic mean, standard deviation and correlation coefficient values with regard to pre-service teachers' self-control, religiousness, intellectualism, social skill, honesty values and social entrepreneurship are displayed in Table 1.

According to Table 1, there are moderately positive relationships between pre-service teachers' values, namely self-control $(\mathrm{r}=.39 ; p<.01)$, religiousness $(\mathrm{r}=.43 ; p<.01)$, social skill $(\mathrm{r}=.42 ; p<.01)$ and honesty $(\mathrm{r}=.36 ; p<.01)$ and their social entrepreneurship levels. There is a low positive relationship between intellectualism and their social entrepreneurship $(\mathrm{r}=.20 ; \quad p<.01)$. Highest relationship is between religiousness and social entrepreneurship $(\mathrm{r}=.43 ; p<.01)$, whereas the lowest relationship is between intellectualism and social entrepreneurship $(\mathrm{r}=.20 ; p<.01)$. The mean score for pre-service teachers' social entrepreneurship is at "mostly" level $(\bar{x}=3.81)$. The mean scores for self-control $(\bar{x}=$ 2.47) and intellectualism $(\bar{x}=2.37)$ are at "agreement" level, while the scores for religiousness $(\bar{x}=2.11)$, social skill $(\bar{x}=2.22)$ and honesty $(\bar{x}=2.30)$ are at "moderate agreement" level. The highest mean score takes place in self-control, while the lowest score takes place in religiousness. The results for regression analysis to what extent pre-service teachers' personal values predict their social entrepreneurships are displayed in Table 2.

Table 1. Arithmetic mean, standard deviation and correlation coefficient values with regard to pre-service teachers' self-control, religiousness, intellectualism, social skill, honesty values and social entrepreneurship

\begin{tabular}{|c|c|c|c|c|c|}
\hline Personal values & Min. & Max. & $\bar{x}$ & Sd & Social Entrepreneurship \\
\hline Social Entrepreneurship & 1.19 & 5.00 & 3.81 & .63 & 1 \\
\hline Self-control & 1.25 & 3.00 & 2.47 & .29 & $.35^{* *}$ \\
\hline Religiousness & 1.20 & 3.00 & 2.11 & .37 & $.43^{* *}$ \\
\hline Intellectualism & 1.00 & 3.00 & 2.37 & .41 & $.20^{* *}$ \\
\hline Social Skill & 1.17 & 3.00 & 2.22 & .32 & $.42^{* *}$ \\
\hline Honesty & 1.17 & 3.00 & 2.30 & .39 & $.36^{* *}$ \\
\hline
\end{tabular}

$* * \mathrm{p}<.01$

Table 2. The results for regression analysis with regard to pre-service teachers' personal values prediction for their social entrepreneurships

\begin{tabular}{|c|c|c|c|c|c|c|c|c|c|}
\hline Variables & B & $\mathbf{S D}_{\mathbf{B}}$ & $\boldsymbol{\beta}$ & $\mathbf{T}$ & $\mathbf{p}$ & $\mathbf{R}$ & $\mathbf{R}^{2}$ & $\mathbf{F}$ & $\mathbf{p}$ \\
\hline Stable & 2.56 & .29 & & 5.82 & .040 & \multirow{6}{*}{.63} & \multirow{6}{*}{.40} & \multirow{6}{*}{51.46} & \multirow{6}{*}{.000} \\
\hline Self-control & .29 & .09 & .13 & 3.05 & .002 & & & & \\
\hline Religiousness & .51 & .07 & .29 & 7.28 & .000 & & & & \\
\hline Intellectualism & .19 & .06 & .13 & 3.22 & .001 & & & & \\
\hline Social skill & .53 & .08 & .27 & 6.21 & .000 & & & & \\
\hline Honesty & .39 & .06 & .24 & 5.97 & .000 & & & & \\
\hline
\end{tabular}

$* * \mathrm{p}<.01$ 
It is seen from Table 2 that pre-service teachers' self-control $(\beta=.13 ; p<.01)$, religiousness $(\beta=.30 ; p$ $<.01)$, intellectualism $(\beta=.13 ; p<.01)$, social skill $(\beta$ $=.27 ; p<.01)$ and honesty $(\beta=.24 ; p<.01)$ sub-dimensions significantly predicted their social entrepreneurship characteristics and accounted for $40 \%$ of the total variance.

\section{Conclusions and Discussion}

The purpose of this research is to identify to what degree pre-service teachers' personal values predict their social entrepreneurship characteristics. In this context, the mean scores for pre-service teachers' perceptions with regard to their personal values and social entrepreneurship characteristics were firstly calculated. Then, the relationship between their self-control, religiousness, intellectualism, social skill and honesty values and their social entrepreneurship characteristics was examined. And lastly, regression analysis was conducted to what extent the values predict their social entrepreneurship characteristics.

As a result of the data analysis, it was seen that the mean scores for pre-service teachers' personal values from the highest to lowest ones are as follows; self-control, intellectualism, honesty, social skill and religiousness. While pre-service teachers' prior preference was self-control among the values, their least preference was religiousness. This result coincides with the one derived from the research conducted by Gökçe [43]. Self-control value stems from a person's needs to be dominant over his/her life be autonomous and independent [40]. In this respect, the fact that pre-service teachers primarily prefer self-control value indicates that they do not want anybody to interfere with their emotions, thoughts and behaviors. It can be stated that pre-service teachers give much more importance to the values concerned with self-control such as freedom and independence depending on their increasingly experiences in education [45]. The findings obtained from the research by Schwartz [47] support this result. In this research, peoples' more involvement in formal training process contributes to developing their self-control value. The fact that pre-service teachers less prefer religiousness value compared with the other values is an unexpected result for Turkey. Because it was revealed in the previous research conducted with the university students in Turkey that they have religious tendencies at somewhat higher level $[48,49]$. When the mean scores for pre-service teachers' social entrepreneurship characteristics are examined, it was found out that they were at mostly level. In the light of these results, it can be claimed that pre-service teachers are not indifferent to social and environmental problems, are self-confident to overcome these problems and can take a risk to come up with creative solution models.

It was seen that there are positive significant relationships between pre-service teachers' self-control, religiousness, intellectualism, social skills and honesty values and their social entrepreneurship characteristics. As a result of the regression analysis to identify these values' prediction for the social entrepreneurship characteristics, it was revealed that self-control $(\beta=.13 ; p<.01)$, religiousness $(\beta=.30 ; p<.01)$, intellectualism $(\beta=.13 ; p$ $<.01)$, social skill $(\beta=.27 ; p<.01)$ and honesty $(\beta=.24 ; p$ $<.01)$ significantly predicted pre-service teachers' social entrepreneurship characteristics and accounted for $40 \%$ of the total variance. It is seen that the religiousness value mostly predicted the social entrepreneurship characteristics. Religious beliefs have been known to be an important component of entrepreneurship for a long time [50]. A number of social entrepreneurs indicate that their religious beliefs and faith-based groups' supports such as mosques and churches help them exhibit behaviors for social entrepreneurship [51]. It has historically been known that there is a strong bond between religious groups and entrepreneurship activities. So, religious belief groups shape their members' behaviors by assigning a variety of responsibilities [52]. Besides, helping others is a common theme in a number of religious traditions and it is seen that there is a relationship between religiousness and aid as a result of the scientific researches [53]. Other individuals or religious organizations generally ensure individuals to acquire religious values. The fact that religious values take encouraging roles in cooperation, solidarity and sharing among people, has a significant role in enabling religious individuals to be sensitive to social matters. Drakopoulou Dodd and Seaman [54] advocate that individuals' religious beliefs positively affect their entrepreneurship activities in terms of three aspects. They are as follows: individual's decision to be an entrepreneur, managing his/her own entrepreneurship activities and preference to form intrinsic and extrinsic social networks.

The other two predictors for social entrepreneurship values are social skill and honesty values. It is known that social entrepreneurs have extroverted personality characteristics [25]. Extroverted individuals can easily interact with other people, like being with people and are inclined to be in cooperation [55]. It is obvious that extroverted individuals have higher social skills. The ability to establish qualified relationships with others is mostly regarded as one of the necessary conditions to benefit from opportunities and innovations in entrepreneurship [24]. Brandstatter [56] stressed out that social entrepreneurs need to have social skills to establish a social network and be continuously in connection with others. Social networks are important for entrepreneurs due to their economic and personal supports [57]. Being in contact and cooperation with other people are inevitable to understand social matters, determine and identify limits and come up with models for solutions. These require social entrepreneurs to have higher social skills. According to Pearce and Doh [58], one of the most important 
characteristics of social entrepreneurs is the ability to direct and mobilize the efforts of all institutions and people who seek to create social value. In this respect, the fact that social entrepreneurs realize their aims to solve social matters depends on establishing a communication network among stakeholders based on confidence, sincerity and cooperation. This is just possible with social entrepreneurs' having personal values such as social skills and honesty.

In the current research, it is seen that self-control and intellectualism values in the least predict their social entrepreneurships. It is important for social entrepreneurs to be independent and manage their emotions and behaviors. It is revealed in the research conducted by Akar and Üstüner [24] that the ability to understand and manage one's and others' emotions positively affects individual's social entrepreneurship behaviors. The enterprises to solve social and environmental matters at the beginning can sometimes cause anxiety and stress in individuals and this can negatively influence their social entrepreneurship behaviors. The individuals who have control over their emotions and behaviors can sustain their efforts to create social values by changing their negative emotions to positive ones [24]. The fact that social entrepreneurs are curious and knowledgeable about regional and national issues will enable them to be aware of social matters, understand the matters and create rational and creative solutions for the matters. In this regard, self-control and intellectualism values are important for social entrepreneurs. To make a general evaluation, the values an individual embraces have an important role in increasing his/her sensitivity to social matters and initiating and keeping solution process. It can be argued that education institutions should be in struggle to get the related values be acquired.

\section{REFERENCES}

[1] Human Development Report, Human Development for Everyone, Online available from http://hdr.undp.org/sites/ default/files/2016_human_development_report.pdf

[2] J. G. Dees. The meaning of "social entrepreneurship". Comments and suggestions contributed from the Social Entrepreneurship Founders Working Group. Durham: Center for the Advancement of Social Entrepreneurship, Fuqua School of Business, Duke University. Online available from http://www.caseatduke.org/documents /dees_sedef.pdf

[3] B. Kümbül Güler. (2008). Sosyal girişimciliği etkileyen faktörlerin analizi, Turkey, Doctoral dissertation, Dokuz Eylül Universitey, İzmir, 2008.

[4] L. Snellman. Social Entrepreneurship: Making change in the world? Journal of Logistics, Informatics and Service Science, Vol.3, No.1, 1-25, 2016.

[5] O. M. Lehner. Crowdfunding social ventures: A model and research agenda. Venture Capital, Vol.15, No.4, 289-31, 2013.

[6] P. D. Corner, M. Ho. How opportunities develop in social entrepreneurship. Entrepreneurship Theory and Practice, Vol.34, No.4, 635-659, 2010.

[7] S. Thake, S. Zadek. Practical People, noble causes: How to support community-based social entrepreneurs. Executive Summary, New Economics Foundation, 1997.

[8] C. W. Letts, L. D. Brown, S. H. Alvord, Social entrepreneurship: Leadership that facilitates societal transformation. An exploratory study, Online available from https://dspace.mit.edu/handle/1721.1/55803

[9] T. Reis. Unleashing the new resources and entrepreneurship for the common good: A scan, synthesis and scenario for action. Online available from https://www.issuelab.org

[10] A. Nicholls. The legitimacy of social entrepreneurship: reflexive isomorphism in a pre-paradigmatic field. Entrepreneurship Theory and Practice, Vol.34, No.4, 611-633, 2010.

[11] C. Borzaga, S. Depedri. When social enterprises do it better: Efficiency and efficacy of work integration in Italian social cooperatives, in S. Denny, F. Simmon (Eds.) Social Enterprises. Accountability and Evaluation around the World. Routledge, London, pp. 85-101, 2013.

[12] T. L. Miller, M. G. Grimes, J. S. McMullen, T. J. Vogus. Venturing for others with heart and head: How compassion encourages social entrepreneurship. Academy of Management Review, Vol.37, No.4, 616-640, 2012.

[13] S. A. Zahra, E. Gedajlovic, D. O. Neubaum, J. M. Shulman. A typology of social entrepreneurs: Motives, search processes and ethical challenges. Journal of Business Venturing, Vol.24, No.5, 519-532, 2009.

[14] B. Sivathanu, P. V. Bhise. Challenges for social entrepreneurship. Special Issue for National Conference on Recent Advances in Technology and Management for Integrated Growth, GNI Nagpur, India, 2013.

[15] W. Drayton. The citizen sector: Becoming as entrepreneurial and competitive as business. California Management Review, Vol.44, No.3, 120-132, 2002.

[16] K. Aileen Boluk, Z. Mottiar. (2014). Motivations of social entrepreneurs: Blurring the social contribution and profits dichotomy. Social Enterprise Journal, Vol.10, No.1, 53-68, 2014.

[17] A. M. Peredo, M. McLean. Social entrepreneurship: A critical review of the concept. Journal of World Business, Vol.41, No.1, 56-65, 2006

[18] J. Mair, I. Marti. Social entrepreneurship research: A source of explanation, prediction, and delight. Journal of World Business, Vol.41, No.1, 36-44, 2006.

[19] J. Austin, H. Stevenson, J. Wei - Skillern. Social and commercial entrepreneurship: same, different, or both? Entrepreneurship Theory and Practice, Vol.30, No.1, 1-22, 2006.

[20] D. Henton, J. Melville, K. Walesh. The age of the civic entrepreneur: Restoring civil society and building economic community. National Civic Review, Vol.86, No.2, 149-156, 
1997.

[21] K. Deáková, K. Drážovská, D. Grznárik, I. Kondášová. Entrepreneurship, SOPK, Bratislava, 2010.

[22] H. Knőrr, C. Alvarez, D. Urbano. Entrepreneurs or employees: a cross-cultural cognitive analysis. Int Entrep Manag J., Vol.9, 273 - 294, 2013.

[23] E. Shaw, S. Carter. Social entrepreneurship: Theoretical antecedents and empirical analysis of entrepreneurial processes and outcomes. Journal of Small Business and Enterprise Development, Vol.14, No.3, 418-434, 2007.

[24] H. Akar, M. Üstüner. Mediation role of self-efficacy perceptions in the relationship between emotional intelligence levels and social entrepreneurship traits of pre-service teachers. Journal of Education and Future, Vol.12, 95-115, 2017.

[25] H. Akar, S. Aydın. The predictive level of social entrepreneurship characteristics of the personality traits of preservice teachers. The journal of Academic Social Science, Vol.3, N0.12, 425-436, 2015.

[26] C. A. Hemingway. Personal values as a catalyst for corporate social entrepreneurship. Journal of Business Ethics, Vol.60, No.3, 233-249, 2005.

[27] S. H. Schwartz. Are there universal aspects in the structure and contents of human values? Journal of Social Issues, Vol.50, No.4, 19-45, 1994

[28] S. H. Schwartz, W. Bilsky. Toward a theory of the universal content and structure of values: Extensions and cross-cultural replications. Journal of Personality and Social Psychology, Vol.58, No.5, 878, 1990.

[29] M. Rokeach. The nature of human values. Free Press, Detroit, 1973.

[30] S. Roccas, L. Sagiv, S. H. Schwartz, A. Knafo. The big five personality factors and personal values. Personality and Social Psychology Bulletin, Vol.28, No.6, 789-801, 2002.

[31] W. Bilsky, S. H. Schwartz, S. H. Values and personality. European Journal of Personality, Vol.8, No.3, 163-181, 1994.

[32] Y. L. Shao. An exploratory examination of the impact of personal values on sport consumption preferences and behaviors: A cross-cultural study, USA, Doctoral dissertation, The Ohio State University, 2002.

[33] C. J. Clawson, D. E. Vinson. Human values: A historical and interdisciplinary analysis. Advances in Consumer Research, Vol.5, No.1, 396-402, 1978.

[34] D. Suar, R. Khuntia. Influence of personal values and value congruence on unethical practices and work behaviour. Journal of Business Ethics, Vol.97, No.3, 443-460, 2010.

[35] A. Bardi, S. H. Schwartz. Values and behavior: Strength and structure of relations. Personality and Social Psychology Bulletin, Vol.29, No.10, 1207-1220, 2003.

[36] P. E. Tetlock. A value pluralism model of ideological reasoning. Journal of Personality and Social Psychology, Vol.50, No.4, 819, 1986.

[37] L. Sagiv, S. H. Schwartz. Value priorities and readiness for out-group social contact. Journal of Personality and Social Psychology, Vol.69, No.3, 437, 1995.

[38] B. Verplanken, R. W. Holland. Motivated decision making: effects of activation and self-centrality of values on choices and behavior. Journal of Personality and Social Psychology, Vol.82, No.3, 434, 2002

[39] A. Bardi. Relations of values to behavior in everyday situations. Unpublished doctoral dissertation. The Hebrew University, Jerusalem, 2000.

[40] S. H. Schwartz. Universals in the content and structure of values: Theoretical advances and empirical tests in 20 countries. Advances in Experimental Social Psychology, Vol.25, 1-65, 1992.

[41] W. A. Scott. Values and organizations: A study of fraternities and sororities. Rand McNally, Chicago, 1965.

[42] A. S. Cheng, K.R. Fleischmann. Developing a meta inventory of human values. Proceedings of the Association for Information Science and Technology, Vol.47, No.1, 1-10, 2010 .

[43] Y. B. Gökçe. The Evaluation of the university students of personal values according to independent variables, Turkey, Unpublished master's thesis, Abant Izzet Baysal University, Bolu, 2004

[44] L. Cohen, L. Manion, K. Morrison. Research methods in education. (6th Ed.), Taylor \& Francis e-Library, 2007.

[45] T. Konakl1, N. Gögüş. Pre-service Teachers' Social Entrepreneurship Qualifications Scale: Validity and Reliability Study. Gazi University Journal of Gazi Educational Faculty, Vol.33, No.2, 373- 391, 2013

[46] M. L. Kohn, S. Schooler. Work and personality: An inquiry into the impact of social stratification. Ablex Pub., 1983.

[47] S. H. Schwartz. Basic human values: An overview. Online available from http://www. yourmorals.org/Schwartz

[48] K. Y1lmaz. The relationship between personal values and religious tendency among Turkish university students, Balikesir University The Journal of Social Sciences Institute, Vol.16, No.2, 129- 146, 2013.

[49] A. Çarkoğlu, E. Kalaycıŏlu. Türkiye'de dindarlık: uluslararası bir karşılaștırma. Sabancı Üniversitesi İstanbul Politikalar Merkezi. Online available from http://research. sabanciuniv.edu/13119/1/Rapor_Kamu-dindarl\%C4\%B1k. pdf.

[50] M. Weber. The Protestant ethic and the" spirit" of capitalism and other writings. Penguin, 2002.

[51] British Council, Religion and belief equality guide Online available from https://www.britishcouncil.org.

[52] R. James. Handle with care: Engaging with faith-based organisations in development, Development in Practice, Vol.21, No.1, 109-117, 2011.

[53] C. J. Einolf. The link between religion and helping others: The role of values, ideas, and language. Sociology of Religion, Vol.72, No.4, 435-455, 2011.

[54] S. Drakopoulou Dodd, P. Seaman. Religion and the self-employed: some empirical data. Entrepreneurship Theory and Practice, Vol.23, No.1, 71-86, 1998. 
[55] V. Benet-Martinez, O. P. John. Los Cinco Grandes across cultures and ethnic groups: Multitrait-multimethod analyses of the Big Five in Spanish and English. Journal of Personality and Social Psychology, Vol.75, No.3, 729, 1998.

[56] H. Brandstätter. Becoming an entrepreneur-a question of personality structure? Journal of Economic Psychology, Vol.18, No.2, 157-177, 1997.
[57] J. K. H. Nga, G. Shamuganathan. The influence of personality traits and demographic factors on social entrepreneurship starts up intentions. Journal of Business Ethics, Vol.95, No.2, 259-282, 2010.

[58] J. A. Pearce II, J. P. Doh. The high impact of collaborative social initiatives. MIT Sloan Management Review, Vol.46, No.3, 30, 2005. 